Vol 1. No 1. Februari 2017

\title{
DETEKSI FRAGMEN DNA RENDAH PENGKODE GEN SITOKROM B (cyt b) BABI PADA SAMPEL MIE INSTAN MENGGUNAKAN METODE POLYMERASE CHAIN REACTION (PCR)
}

\author{
Winarsih $^{* 1}$, Khoirun Nihayati, Romyun Alyv Khoiriyah', \\ ${ }^{1}$ Balai Besar Pengawas Obat dan Makanan di Surabaya, \\ Program Studi Biologi UIN Sunan Ampel Surabaya \\ *Email: khoirun.nihayati15@gmalil.com
}

\begin{abstract}
ABSTRAK
Mie instan merupakan makanan yang sangat digemari oleh masayarakat Indonesia, selain cara penyajiannya yang cepat dan harganya terjangkau, rasa dari mie instan juga tidak kalah dengan makanan lainnya. Baru-baru ini sedang marak produk mie instan yang di impor dari Korea dan saat ini sedang digandrungi para remaja di Indonesia. Produk tersebut diduga mengandung babi, dugaan tersebut kemudian ditindak lanjuti oleh Badan Pengawas Obat dan Makanan selaku instansi yang berwenang untuk melakukan pengawasan terhadap obat dan makanan dan juga melakukan pengujian terhadap produk obat, makanan, maupun kosmetik yang diduga mengandung bahan berbahaya atau mengandung babi yang tidak umum dikonsumsi di Indonesia karena mayoritas penduduknya yang muslim. Proses pengujian sampel tersebut dilakukan dengan metode Polymerase Chain Reaction (PCR) yang spesifik terhadap DNA suatu organisme. Berdasarkan penelitian yang telah dilakuakan didapatkan hasil dari 18 sampel mie instan, diketahui sampel dengan nomor 16 positif mengandung DNA cytb babi. Hal tersebut diketahui dari munculnya pita DNA pada daerah $149 \mathrm{bp}$.
\end{abstract}

Kata Kunci: Mie instan, DNA cytb babi, PCR

\section{PENDAHULUAN}

Dewasa ini kemajuan teknologi semakin berkembang pesat, baik dalam bidang ilmu pengetahuan, kesehatan dan juga pangan. Perkembangan teknologi tersebut menyebabkan semakin mudahnya produk-produk dari luar negeri yang masuk ke Indonesia. Salah satunya dalam bidang pangan, seiring dengan perkembangan zaman, semakin banyak diproduksi makanan-makanan instan, seperti kopi instan, bumbu masak instan, dan yang paling populer bagi masyarakat di Indonesia yaitu mie instan. Mie instan merupakan makanan yang sangat digemari oleh masayarakat Indonesia, selain cara penyajiannya yang cepat dan harganya terjangkau, rasa dari mie instan juga tidak kalah dengan makanan lainnya.

Baru-baru ini sedang marak produk mi instan yang di impor dari Korea dan saat ini sedang digandrungi para remaja di Indonesia. Produk tersebut diduga mengandung babi, dugaan tersebut kemudian ditindak 
lanjuti oleh Badan Pengawas Obat dan Makanan selaku instansi yang berwenang untuk melakukan pengawasan terhadap obat dan makanan dan juga melakukan pengujian terhadap produk obat, makanan, maupun kosmetik yang diduga mengandung bahan berbahaya atau mengandung babi yang tidak umum dikonsumsi di Indonesia karena mayoritas penduduknya yang muslim.

Oleh karena itu pada pengujian kali ini Balai Besar Pengawas Obat dan Makanan melakukan pengujian terhadap mie instan Impor yang diduga mengandung DNA cytb babi dengan menggunakan metode Polymerase Chain Reaction (PCR).

\section{METODE}

Penelitian ini dilaksanakan di Laboratorium PCR Balai Besar Pengawas Obat dan Makanan di Surabaya Jl. Karangmenjangan No. 20, Gubeng, Airlangga, Gubeng Kota Surabaya, Jawa Timur 60286.

Alat alat yang digunakan dalam penelitian ini adalah Tip tahan aerosol 1$1000 \mu \mathrm{L}$, pipet mikro ukuran $20 \mu \mathrm{L}, 100$ $\mu \mathrm{L}, 1000 \mu \mathrm{L}$, neraca analitik, centrifuge, micro centrifuge, waterbath, tabung centrifuge $1.5 \mathrm{ml}, 2 \mathrm{ml}, 50 \mathrm{ml}$, kolom maxi dan mini, tabung penampung, nanodrop, perangkat elektroforesis agarose horizontal, sistem dokumentasi gel, LAF (Laminar Air Flow), Thermocycler PCR System 9700.

Sedangkan bahan yang digunakan adalah sampel mie instan yang diduga mengandung babi (total 18 sampel dengan merek produksi dan rasa yang berbeda-beda), agarosa molecular grade, DNA ladder $1 \mathrm{~kb}$ dan 100 bp. Dapar CTAB pH 8.0 yang mengandung $20 \mathrm{~g} / \mathrm{L}$ CTAB, 1.4 M NaCl, 0.1 M Tris HCl, 20 mM EDTA; Kit Qiagen yang terdiri dari dapar AL, dapar AW 1 (keduanya mengandung guanidin hidroklorida), dapar AW 2, dapar AE dapar elusi) dan protease; ethanol absolut p.a; dapar PB; dapar PE; 5x dapar PCR tanpa magnesium klorida; Bovine Serum Albumine; larutan $\mathrm{MgCl}_{2}$ 25 mM; larutan campuran dNTPmix 10 mM; DNA hasil isolasi; cytb forward primer 5' - ATG AAA CAT TGG AGT AGT CCT ACT ATT TAC C -3'; cytb reverse primer 5'- CTA CGA GGT CTG TTC CGA TAT AAG G - 3'; DNA Taq Polymerase 5 $\mathrm{UI} / \mu \mathrm{L}$; dapar TAE $1 \mathrm{x}$ mengandung $40 \mathrm{mM}$ Tris-Asetat; 1 mM EDTA; SYBR Safe 10.000 x dalam DMSO.

\section{Persiapan Sampel}

Masing-masing sampel mie instan dihancurkan kemudian dicampur dengan bumbu dan pelengkap yang terdapat didalam kemasan, kemudian dihomogenkan sampai tercampur rata. 
Sampel mie kemudian ditimbang sebanyak 3 gram dan dimasukkan kedalam tabung centrifuge steril $50 \mathrm{ml}$.

\section{Isolasi DNA Sampel Mie Instan}

Sampel mie pada tabung centrifuge steril ditambahkan $300 \mu \mathrm{L}$ protease serta $15 \mathrm{ml}$ dapar CTAB (Food Lysis Buffer), campuran tersebut dihomogenkan dengan menggunakan vortex mixer dan diinkubasi dalam waterbath pada suhu $65^{\circ} \mathrm{C}$ selama 45 menit. Selanjutnya, campuan dicentrifuge pada 3000 x g selama 10 menit. Sebanyak $10 \mathrm{ml}$ supernatan dipindahkan kedalam tabung centrifuge steril $50 \mathrm{ml}$, lalu ditambahkan $10 \mathrm{ml}$ dapar AL, campuran dibolak-balik perlahan hingga homogen, dan diinkubasi kembali pada suhu $65^{\circ} \mathrm{C}$ selama 15 menit. Setelah itu, ditambahkan ethanol 96\% PA sebanyak $20 \mathrm{ml}$ kedalam campuran yang masih dalam keadaan hangat, kemudian dibolak-balik perlahan. Campuran yang telah homogen, dituang kedalam kolom maxi yang telah terpasang pada Vacum Manifold System, kemudian vakum dinyalakan. Setelah campuran yang terdapat didalam kolom maxi habis, kemudian ditambahkan dapar AW 1 sebanyak $10 \mathrm{ml}$, dan divakum kembali. Setelah itu ditambahkan dapar AW 2 sebanyak $10 \mathrm{ml}$ dan divakum kembali. Setelah proses vakum selesai, kolom maxi dipindahkan kedalam tabung penampung steril dan dicentrifuge pada $4000 \mathrm{x}$ g selama 5 menit. Kemudian ditambahkan dapar AE sebanyak $800 \mu \mathrm{L}$ tepat dibagian tengah, kolom maxi dibiarkan selam 5 menit. Setelah itu, kolom maxi dicentrifuge pada 4000 x g selama 10 menit. Dapar AE hasil sentrifugasi dipipet dan diteteskan kembali ke kolom tersebut, kemudian didiamkan kembali selam 5 menit. Kolom maxi tersebut di centrifuge kembali pada 4000 x g selama 10 menit. Selanjutnya, kolom maxi dibuang dan ditambahkan dapar PB sebanyak $5 \mathrm{ml}$ pada tabung penampung yang mengandung DNA, kemudian tabung dibolak-balik perlahan sampai homogen. Campuran dipindahkan ke kolom mini kemudian divakum. Setelah itu pada kolom mini ditambahkan dapar PE sebanyak $750 \mu \mathrm{L}$ yang berfungsi untuk melarutkan DNA yang terdapat pada filter kolom mini dan divakum kembali, prosedur tersebut diulangi sebanyak 2 kali. Setelah itu kolom dicentrifuge pada 13.000 x g selama 5 menit. Kemudian, kolom mini dipindahkan pada tabung 1.5 ml steril, dan ditambahkan $50 \mu \mathrm{L}$ dapar AE tepat ditengah kolom serta dibiarkan selam 5 menit, setelah itu kolom di centrifuge pada $13.000 \mathrm{x}$ g selama 5 menit. Dapar AE hasil sentrifugasi dipipet dan diteteskan kembali tepat ditengah kolom tersebut, kemudian didiamkan 
kembali selama 5 menit. Setelah itu kolom tersebut dicentrifuge kembali pada 13.000 x g selama 5 menit. Setelah itu, kolom mini dibuang, dan larutan yang terdapat pada tabung penampung merupakan DNA hasil isolasi dari mi instan. Larutan DNA disimpan pada suhu $-4^{\circ} \mathrm{C}$ apabila tidak langsung digunakan.

\section{Pengukuran Konsentrasi DNA Hasil} Isolasi

DNA hasil isolasi ditentukan kemurniannya menggunakan spektrofotometer UV pada panjang gelombang 260 dan $280 \mathrm{~nm}$, kemudian dihitung perbandingan serapan A260 dan A280. Konsentrasi DNA hasil isolasi ditentukan dengan mengukur serapannya pada panjang gelombang $260 \mathrm{~nm}$. DNA mempunyai kemurnian yang tinggi apabila hasil perbandingan serapan pada panjang gelombang 260/280 $\mathrm{nm}$ berada dalam kisaran 1.8-2.0.

Larutan hasil isolasi DNA diambil sebanyak $5 \mu \mathrm{L}$ menggunakan mikropipet, kemudian diteteskan tepat dibagian tengah kufet dan dimasukkan kedalam alat spektrofotometer UV. Sebelum dilakukan pengukuran terhadap sampel, terlebih dahulu dilakukan pengujian terhadap larutan blanko, dalam hal ini larutan blanko yang digunakan yaitu dapar AE yang merupakan dapar elusi atau pelarut terakhir yang digunakan pada saat isolasi DNA. Hasil pengukuran larutan blanko harus menunjukkan angka nol.

\section{Proses PCR}

Pereaksi untuk proses amplifikasi DNA dicampur dengan volume akhir $50 \mu \mathrm{L}$ untuk satu kali reaksi, yaitu $40 \mu \mathrm{L}$ mastermix dan $10 \mu \mathrm{L}$ DNA hasil isolasi. Larutan mastermix terdiri dari $25 \mu \mathrm{L}$ Go Taq (berisi Taq Polymerase, $\mathrm{MgCl}$, dNTPmix) , $20 \mu \mathrm{M}$ cytb babi forward primer , $20 \mu \mathrm{M}$ cytb babi reverse primer masing- masing sebanyak $10 \mu \mathrm{L}$ dan 13 $\mu \mathrm{L}$ nuclease free water. Siklus PCR dilakukan pada kondisi Denaturasi awal : $98^{\circ} \mathrm{C}$ selam 2 menit, dilanjutkan dengan 50 siklus pada kondisi denaturasi pada suhu $95^{\circ} \mathrm{C}$ selama 30 detik, annealing pada suhu $60^{\circ} \mathrm{C}$ selama 30 detik, polimerasi pada suhu $72^{\circ} \mathrm{C}$ selama 40 detik, diakhiri dengan Polimerasi akhir pada suhu $72^{\circ} \mathrm{C}$ selama 3 menit.

\section{Proses Elektroforesis}

Elektroforesis dilakukan dengan menggunakan agarosa $1 \%$ pada kondisi 100 volt, 400 ampere dengan running time selama 75 menit. DNA ladder yang digunakan berukuran 100 bp sebanyak 6 $\mu \mathrm{L}$, DNA template dan kontrol positif sebanyak $10 \mu \mathrm{L}$. Hasil eletroforesis divisualisasi dengan menggunakan sistem dokumentasi gel mengacu pada MA 50/BT/02. Apabila fragmen DNA sampel 
hasil PCR sejajar dengan kontrol positif fragmen DNA cytb babi berukuran 149 bp, maka hasil pengujian dinyatakan positif mengandung fragmen cytb babi.

\section{Teknik analisis data}

Teknik analisis data menggunakan analisis Kuantitatif dan kualitatif. Analisis dilakukan dengan pengukuran konsentrasi DNA menggunakan spektrofotometer UV pada serapan panjang gelombang $260 \mathrm{~nm}$ dan $280 \mathrm{~nm}$. Sedangkan analisis kualitatif dilakukan dengan elektroforesis gel agarosa dilanjutkan dengan gel documentation.

\section{HASIL DAN PEMBAHASAN}

Dari serangkaian proses pengujian didapatkan hasil Gel Documentation DNA hasil isolasi dari 18 sampel tidak ditemukan adanya DNA cytb babi pada sampel nomor 1 sampai 5 karena tidak nampak band atau pita DNA yang muncul pada daerah 149 bp (base pair) yang merupakan daerah fragmen DNA cytb babi. Sama halnya dengan sampel nomor 6 sampai 10 tidak ditemukan adanya DNA cytb babi karena tidak nampak band atau pita DNA yang muncul pada daerah 149 bp. Pada sampel nomor 10-15 juga negatif terhadap DNA cytb babi. Akan tetapi pada sampel nomor 16 ulangan kedua (16B) nampak samar-samar pita DNA pada daerah 149 bp. Hal tersebut mengindikasikan bahwa sampel nomor 16 diduga mengandung DNA babi. Untuk memverifikasi hasil temuan tersebut, dilakukan pengulangan uji terhadap sampel nomor 16 dengan 4 kali ulangan dengan prosedur yang sama. Hasilnya menunjukkan dari 4 kali ulangan yang dilakukan ditemukan pita DNA pada daerah 149 bp. (Gambar hasil gel documentation dapat dilihat pada lembar Lampiran).

\section{KESIMPULAN}

Berdasarkan hasil penelitian yang telah dilakukan, disimpulkan bahwa Dari hasil pengujian pada 18 sampel mie instan yang diduga mengandung fragmen DNA cytb babi, hanya sampel nomor 16 yang positif mengandung fragmen DNA cytb babi.

\section{DAFTAR PUSTAKA}

Anonim. 2012. Mengenal Mie. Diakses pada $28 \quad$ Februari 2017.<http://www.ot.co.id>.

Anonim. TT. Badan Pengawas Obat dan Makanan Republik Indonesia. Diakses pada 3 Februari 2017. <http://www.bpom.go.id>.

Ardi, A., 2012. Validasi Metode Ekstraksi DNA pada Analisis DNA Babi dalam Produk Bakso. Skripsi. Fakultas Matematika dan Ilmu Pengetahuan Alam, Institut Pertanian Bogor, Bogor. 
BPOM. 2008. Info POM. Badan Pengawas Obat dan Makanan Republik Indonesia. Vol. 9, No. 2

Campbell, N.A., Reece, J.B., Mitchell, L.G. 2002. Biologi. Alih bahasa lestari, R. et al. safitri, A., Simarmata, L., Hardani, H.W. (eds). Erlangga, Jakarta.

Dalilah, E., 2006. Evaluasi Nilai Gizi Dan Karakteristik Protein Daging Sapi dan Hasil Olahannya. Skripsi. Fakultas Peternakan, Institut Pertanian Bogor, Bogor.

Erwanto, Y., Sugiyono, Rohman, A., dkk., 2012. Identifikasi Daging Babi Menggunakan Metode PCR-RFLP Gen Cytochrome $b$ dan PCR Primer Spesifik Gen Amelogenin. Jurnal Agritech. 32: -

Fatimah, N., 2010. Uji Kuantitatif DNA. Makalah. Yogyakarta.

Fibriana, F., Tuti, W., dan Amin, R., 2010. Deteksi Kandungan Daging Babi pada Bakso yang Dijajakan di Pusat Kota Salatiga Menggunakan Teknik Polymerase Chain Reaction. Jurnal Biosaintifika. 2: 10-17.

Handoyo, D., dan Ari, R., 2001. Prinsip Umum dan Pelaksanaan Polymerase Chain Reaction (PCR) [General Principles and Implementation of Polymerase Chain Reaction]. Pusat Studi Bioteknologi Universitas Surabaya. 9: 17-29.

Mulyana. Y., 2010. Analisis Cemaran Daging Babi pada Kornet Sapi di Wilayah Ciputat dengan Menggunakan Metode Polymerase Chain Reaction (PCR). Skripsi. Fakultas Kedokteran dan Ilmu Kesehatan, Universitas Islam Negeri Syarif Hidayatullah, Jakarta.
Nurul, A. I., 2014. Perbandingan Antara Metode SYBR Green dan Metode Hydrolysis Probe dalam Analisis DNA Gelatin Sapi dan DNA Gelatin Babi dengan Menggunakan Real Time PCR. Skripsi. Fakultas Kedokteran dan Ilmu Kesehatan, Universitas Islam Negeri Syarif Hidayatullah, Jakarta.

Rasyid, S., 2015. Analisis Cemaran Daging Babi pada Produk Bakso Sapi yang Beredar di Wilayah Ciputat Mengguakan Real-Time Polymerase Chain Reaction (PCR) dengan Metode Hydrolysis Probe. Skripsi. Fakultas Kedokteran dan Ilmu Kesehatan, Universitas Islam Negeri Syarif Hidayatullah, Jakarta.

Susilo, A., Soeparno, Tety, H., dkk., 2012. Amplifikasi DNA Gen Meat Tendernes Pada Sapi Bali (Bos sondaicus). Jurnal Ilmu dan Teknologi Hasil Ternak. 7: 19-23

Susanto, E., 2011. Identifikasi Daging Babi Dalam Sosis Melalui Karakterisasi Protein Myofibril. Jurnal Ternak. 02:

Wiji, Bening. 2011. Deteksi Kemurnian Daging Sapi Pada Bakso Di Kota Yogyakarta Dengan Teknik PCRRFLP. Skripsi. Fakultas Teknobiologi, Universitas Atma Jaya, Yogyakarta.

Yusuf, Zuhriana. 2010. PCR. Makalah. FIKK, Universitas Negeri Gorontalo, Gorontalo. 